\title{
A SPORTSÉRÜLÉSEK BÉRKÖLTSÉGKÉNT REALIZÁLT VESZTESÉGEINEK MODELLEZÉSE A MAGYAR LABDARÚGÓ BAJNOKSÁG PÉLDÁJÁN KERESZTÜL
}

\author{
Szalánczi Zoltán
}

\section{Összefoglalás}

A labdarúgás fejlödésével és a játékosok értékének, bérezésének a növekedésével egyre inkább elötérbe kerül a rendelkezésre nem állásuknak a költsége. Itt nem csak az elmaradt haszonra, hanem a bérköltségekre is gondolni kell, hiszen egy játékos, ha nem tud pályára lépni, akkor a bérét továbbra is fizeti a klub. Publikációmban a sérülések gyakoriságához, és az általuk realizált kiesés mértékéhez rendelek pénzügyi értéket az UEFA 2016/17-es szezonra kiadott pénzügyi jelentése alapján. A vizsgált értékeket a Magyar Labdarúgó Bajnokság játékosaira vetitem a Magyar Labdarúgó Szövetség adatbázisa, klubok, és játékosok adatai alapján. Az értékek magyar forintban kerülnek kimutatásra, és a szövetségtöl kapott produktivitási bónuszhoz fogom mérni. Eredményeim szerint már az enyhébb sérülés is nagyobb veszteséget okoz a csapatnak, mint amit egy saját nevelésü fiatal 90 perces szerepeltetése eredményez. Ahogy a súlyosabb sérüléseket vizsgáljuk, tisztán látható, hogy ezek már önmagukban többszörös veszteséget jelentenek, mely egy olyan csapat esetében, aki nem tud megfelelö számú saját nevelésü játékost szerepeltetni akár több mérközés produktivitási bónuszát is felemésztheti.

Kulcsszavak: Labdarúgás, sportgazdaság, bérköltség

JEL: Z2

DOI: 10.33032/acr.2019.9.1.185 


\title{
MODELLING THE LABOUR COST LOSSES REALIZED BY THE SPORT INJURIES THROUGH THE EXAMPLE OF THE HUNGARIAN FOOTBALL CHAMPIONSHIP
}

\begin{abstract}
With the development of football, the increase in the values of the players, and with the growth of wages the cost for the lack of availability more and more come to the front. We don't have to think only about the lost profit, but also about the labour costs, since the club has to pay the salary to a player, who is not available. In my publication I will assign financial values to the rate of injuries, and to the extent of the drop-out by the UEFA 2016/17 financial report. I will project the analysed values to the Hungarian Football Championship with indicators using the data from the Hungarian Football Federation database, clubs and individual player reports. The values will be displayed in Hungarian Forint, and I will measure them to productivity bonus received from the federation. In accordance with my results already the moderate injuries cause bigger losses to the team, as the benefit of a 90 minutes play of a homegrown youngster will result. As we investigate the more severe injuries, it can be seen clear, that these appear as multiple losses, which can consume up several games productivity bonuses, especially for a team, who can't feature adequate number of homegrown players.
\end{abstract}

Keywords: Football, Sports economy, labour cost

JEL: Z2 


\section{Bevezetés}

Közkeletű téma manapság, hogy a testmozgás kedvező hatással van az egészségi állapotra, azonban a hivatásos sportban már több kockázati tényező kapcsolódik a sporthoz. A sérülések többsége megelőzhető lenne a kockázati tényezők mérséklésével, de ezek az intézkedések sok esetben nem állnak rendelkezésre. Az, hogy mi számít sportsérülésnek sokáig nem volt tisztázott. Számos megközelítésben próbálták megfogalmazni, de nem sikerült egy egységes definíciót találni. A futball területéről elindított kezdeményezés eredményeképpen megszületett a sportsérülés definíciója, amely Fuller és társai (2006) megfogalmazása szerint, minden olyan sérülést jelent, ami a sporttevékenység miatt, vagy közben alakul ki. Ezt a meghatározást tovább bonthatjuk kategóriákra, mely szerint megkülönböztetünk orvosi ellátást igénylő, és időhiány okozta sérüléseket. További osztályozási módszerek lehetnek még a sérülések testtájon való elhelyezkedését vizsgáló módszerek, vagy a szöveti károsodás szintjei. Korábbi nemzetközi vizsgálatok kimutatták, hogy minden hatodik orvosi ellátást igénylő sérülés sportolás közben alakult ki (Bahr és mtsai, 2002). Azonban bizonyos sportágak között lényeges eltérések vannak a sérülések gyakorisága között. Például a kézilabda játékosok átlagosan minden 10. mérkőzésen szereznek kisebbnagyobb sérülést, úgy a röplabdázóknál ez a szám lényegesen magasabb. Ök átlagosan minden 100. mérkőzésen sérülnek meg (Fuller et al, 2006). A sérülések súlyosságának tekintetében egy angol vizsgálat kimutatta, hogy a teljes kockázati mutató a labdarúgók között a legmagasabb. Majd ezerszerese a kiemelten magas sérülési kockázatokkal rendelkező foglalkozásokénak (Drawer, Fuller, 2002). Egy frissebb kutatásban Liu és munkatársai (2014) kimutatták 8 holland első osztályú csapat vizsgálatán keresztül a 2009/2010-es szezonban 217 játékos összesen 286 sérülést szenvedett, mely a játékosok 62,7\%-át érintette. Az átlagos sérülés előfordulás 6.2 volt 1000 játékórára vetítve. Ebbe beletartoztak az edzések és meccsek is. Ezekből a vizsgálati eredményekből láthatjuk, hogy a sérülés egy olyan komoly faktor az élsportban, melynek nemcsak a sportszakmai sikerekben, hanem a gazdasági működés eredményességében is nagy szerepe van.

Ekstrand és munkatársai (2009) az UEFA számára készítettek egy tanulmányt, melyben 2001-től 2008-ig vizsgáltak 23 olyan labdarúgó csapatot, mely a szövetség top 50-es listájában szerepelt, ezzel elérve azt, hogy a lehető legmagasabb szintü klubok kerüljenek be csak a vizsgálatba. A vizsgálatban 566000 óra sporttevékenység alatt 4483 sérülés következett be, amely által kimutatható, hogy minden 1000 óra sporttal eltöltött időre 8 sérülés jut. Az is megállapítható volt, hogy a sérülések előfordulása gyakoribb mérkőzésen, mint edzésen. Kiderült az is, hogy egy játékos átlagosan szezononként kétszer sérül meg, ami egy 25 fös keretben 50 sérülést eredményez szezononként. 


\begin{tabular}{|c|c|c|c|c|c|}
\hline Sérülés típusa & Összes & $\mathbf{1 - 3}$ nap & $\mathbf{4 - 7}$ nap & $\mathbf{8 - 2 8}$ nap & > 28 nap \\
\hline Törés & 160 & 7 & 9 & 59 & 85 \\
\hline Egyéb csontsérülés & 26 & 5 & 1 & 6 & 14 \\
\hline $\begin{array}{c}\text { Ficam, részleges } \\
\text { ficam }\end{array}$ & 50 & 5 & 4 & 24 & 17 \\
\hline $\begin{array}{c}\text { Rándulás, } \\
\text { szalagsérülés }\end{array}$ & 828 & 123 & 197 & 334 & 174 \\
\hline Porcsérülés & 124 & 3 & 7 & 41 & 73 \\
\hline Izomsérülés, húzódás & 1581 & 212 & 397 & 765 & 207 \\
\hline Ínszalagsérülés & 327 & 95 & 71 & 101 & 60 \\
\hline Véraláfutás, zúzódás & 744 & 306 & 282 & 141 & 15 \\
\hline Horzsolás & 7 & 3 & 3 & 1 & 0 \\
\hline Seb & 31 & 10 & 11 & 10 & 0 \\
\hline Agyrázkódás & 34 & 5 & 14 & 14 & 1 \\
\hline Idegsérülés & 29 & 7 & 3 & 14 & 5 \\
\hline Gyulladás & 158 & 55 & 36 & 55 & 12 \\
\hline $\begin{array}{c}\text { Túlterheléses } \\
\text { panaszok }\end{array}$ & 285 & 110 & 99 & 59 & 17 \\
\hline Egyéb & 91 & 23 & 27 & 24 & 17 \\
\hline Összesen & 4483 & 971 & 1164 & 1651 & 697 \\
\hline
\end{tabular}

1. táblázat: A labdarúgásban leggyakrabban előforduló sérülések Forrás: Saját szerkesztés Ekstrand (2009) alapján

Megvizsgálták, hogy melyek azok a sérülések, amelyek a leggyakrabban előfordulnak a labdarúgásban, és ezek hatására hány napig nem áll a csapat rendelkezésére a játékos. A leggyakoribb sérülés a combizom húzódás volt, mely a sérülések 17\%-át tette ki, míg a közelítő sérülés a második helyen, már csak 9\%át jelentette a sérüléseknek, mely után a bokaficam és MCL sérülés következett előfordulási gyakoriságban. 


\section{Anyag és módszer}

Kutatásom módszertanát tekintve dokumentumelemzést végeztem, mely során az UEFA 2016/17-es bajnoki évről kiadott pénzügyi jelentését vizsgáltam. A beszámoló tartalmazza az UEFA tagállamok sportvállalkozásai által személy jellegű ráfordításként kifizetett átlagos összegeit, melyet tovább bont az egyéb személyzet és a labdarúgók számára kifizetett bérköltségekre is. További anyagként felhasználtam a Magyar Labdarúgó Szövetség adatbankjátés IFA rendszerét az egy csapatban található játékosok átlagos számának a meghatározására. Ezeknek az adatoknak a segítségével kiszámoltam az egy személyre jutó éves bért, majd tovább bontottam a játékosok által realizált napi bérre, melyet a klub fizet nekik. A sérülések súlyosságának meghatározására Ekstrand (2009) UEFA számára elkészített tanulmányát vettem alapul. A kutatásban meghatározott sérülések súlyosságuk alapján vannak rangsorolva, melyekből minden kategória középértékével kalkuláltam. Az így kapott értékhez hozzárendeltem a sportvállalkozások által kifizetett bérek napi átlagát, ami a sérülések bérként realizált veszteségeit tükrözik. Ahhoz, hogy megfelelően szemléltessem ezeknek az összegnek a nagyságát, a MLSZ 2018-ban bevezetett produktivitási pontot veszem alapul. Ez alapján egy saját nevelésű játékos, ha a pályán van 90 percet az NB1-ben, akkor 360000 forintot keres nevelő egyesületei számára. Összevetésemből kiderül, hogy egy sérülés hogyan aránylik ehhez az összeghez.

\section{Eredmények}

A sérülésekkel kapcsolatosan felmerülő költségeket a játékosok által kihagyott napok számából kalkuláltam. Ahhoz, hogy a teljes Magyar első osztályú bajnokságot felölelő vizsgálatot tudjak végezni, a 2016-os UEFA által kiadott pénzügyi benchmarking jelentést felhasználva kiszámoltam az egy napra eső átlagos fizetését egy Magyarországon futballozó játékos esetében. A jelentés a 2016/17-es szezon adatait használja, így én is ennek a szezonnak a Magyar Labdarúgó Szövetség által közölt adataival kalkuláltam. A beszámoló azért az elérhető legpontosabb módja az egy főre jutó bérekkel való kalkulációnak, mert az NB1-es csapatok számára kötelező évente a klublicenc feltétel rendszeréből adódóan ún. UEFA pénzügyi beszámolót is készíteni, melyben a személy jellegű ráfordítások tartalmazzák a játékosok számára bónuszként, vagy teljesítménybérként kifizetett költségeket is. 


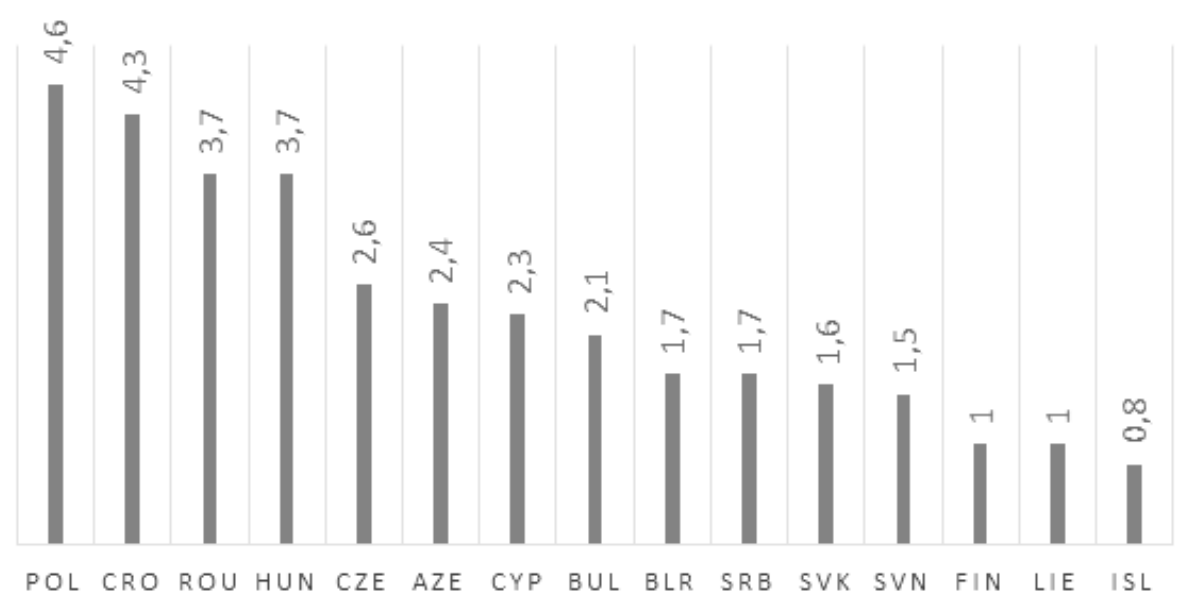

1. ábra: A játékosok bérére fordított kiadások rangsora országonként

Forrás: Saját szerkesztés UEFA (2018) alapján

Az 1. ábrából látható, szembetűnő, hogy a 2015-ös évhez viszonyítva 7\%-os emelkedés tapasztalható a bérekben (Bácsné et al., 2018). Illetve megfigyelhetö, hogy a 12 csapatos bajnokságban egy csapat átlagos bérekre fordított összege 3,7 millió euró.

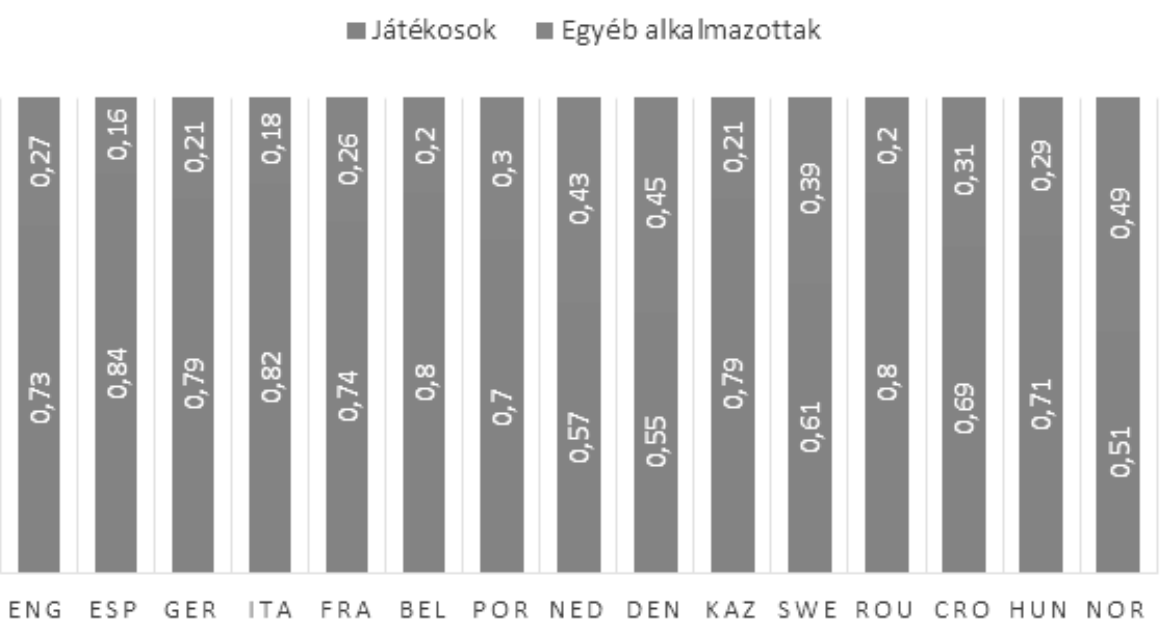

\section{2. ábra: A bérek megoszlása}

Forrás: Saját szerkesztés UEFA (2018) alapján 
A jelentés tartalmazza a magyar klubok átlagos bérköltségét a 2016-os pénzügyi évre, de ez az összes alkalmazott, köztük az egyéb alkalmazottak juttatásait is magába foglalja. Ha a fenti ábrát megtekintjük, akkor látjuk, hogy ennek az összegnek a 71\%-a az egyéb alkalmazottaktól mentes, kizárólag játékosokra fordított bér. Ebből következik, hogy a 3,7 millió euróból 2,627 millió euró kerül közvetlenül a játékosokhoz.

A csapatok játékoskeretének a mérete változó volt a 2016/2017-es szezonban, így, ennek az átlagát kellett venni, hogy megkaphassuk a játékosok egy före eső bérét. Maga a keretek átlagos mérete pontosan 27, így ebből kifolyólag 97296 euró egy játékos átlagos éves bére.

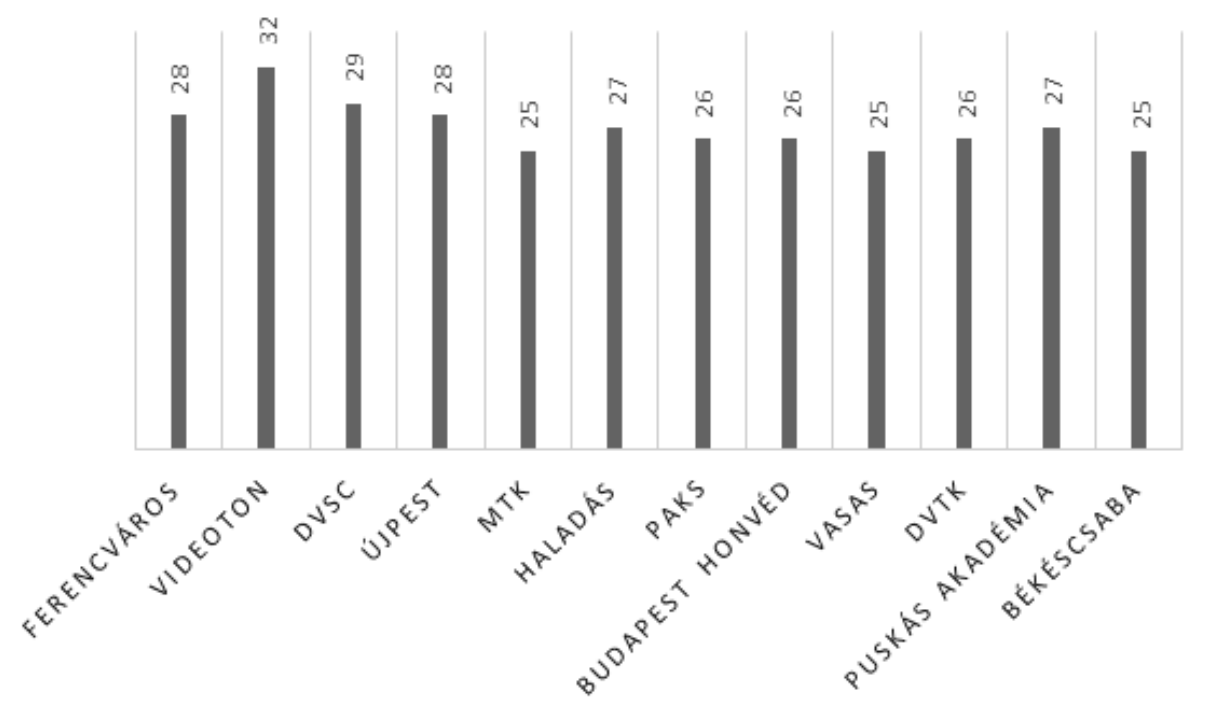

\section{3. ábra: Az NB1-es csapatok játékosainak száma 2016/17-es szezonban Forrás: Saját szerkesztés}

A végső eredmény eléréséhez a játékosok éves bérköltségét elosztottam 365-tel, így megkaptam az egy napi átlagos keresetét egy Magyar NB1-es játékosnak, ami felkerekítve 267 euró. Ez a jelentés kiadását követő időszakban, 2018.06.26-én meghatározott 325 forintos MNB euró árfolyamon átváltva napi 86634 forintnak felel meg. Ekkora összeget költ bérköltségként egy csapat egy játékosára naponta. 


\section{A labdarúgásban előforduló sérülésekkel kapcsolatos költségek kiszámítása}

A sérülések fajtájával és időtartamával foglalkozó táblázatból kiemeltem 4 sérülés típust, súlyosságukat tekintve. Ezeknek a sérüléseknek a költségét a játékos bérköltségével és a sérülés hosszúságának megfelelően kívánom meghatározni. Számításaim során az indirekt költségeket, úgy, mint az elmaradt haszon és a játékos pótlására fordított költségeket sem veszem figyelembe. Minden sérülésnél a tanulmányban meghatározott időintervallumok középértékét veszem figyelembe a kihagyott napok számában, hogy a lehető legközelebb jussak a valósághoz. A sérülések kezeléséhez igénybe vett szolgáltatásokat és esetleges műtéti beavatkozásokat ebben a kimutatásban nem kívánom számításba venni. A felépülési időt a tanulmányban meghatározott módon kívánom kezelni, ahol azt tekintették felépült játékosnak, aki a sérülés bekövetkezte után újra teljes értékủ edzésmunkát képes végezni és a csapatedzésen rendelkezésre áll.

\section{Rövid lefolyású sérülések (1-3 nap):}

Ennek a sérülésnek az előfordulása a legkisebb, illetve a tanulmányban vizsgált adatok alapján a lefolyása is gyors, 1-3 napra tehető. A kezelése nem igényel különösebb beavatkozást, a jegelés és pihentetés a jellemző rá. Ha a korábban megállapított napi bérköltséget vesszük alapul, úgy az átlagos 2 nap kiesés a klub számára 173268 Ft kiadás a játékossal kapcsolatos személy jellegű ráfordítások tekintetében. Ilyen sérülések lehetnek az ínszalag és egyéb húzódások, rándulások, vérömlenyek kialakulásai ütközés vagy esés hatására, valamint a gyulladások a szervezetben, hogy csak néhányat említsek meg.

\section{Közepes lefolyású sérülések (4-7 nap):}

Ennek a sérülésnek a gyógyulása már rosszabb esetben egy hetet is igénybe vehet, amely valószínủleg egy mérkőzést is érint már a bajnoki ritmusban. Ha a középső értéket tekintjük a sérüléssel eltöltött napok számában, akkor 5,5 napot tölt el a játékos kényszerpihenőn, melynek a bérköltségekben kifejezett „ára” 476487 Ft. 


\section{Hosszabb lefolyású sérülések (8-28 nap):}

Ez a sérülés típus már lényegesen komolyabb, és a kezelése is sokkal hosszabb időt vesz igénybe. A sérüléssel átlagosan eltöltött idő 8-28 napig terjed, melynek középső értékét, azaz a 18-at kívánom felhasználni. Tehát ha egy játékos 18 napig nem áll a csapat rendelkezésére, az 1559412 Ft bérköltséget jelent a klub számára. Ez az összeg már igencsak jelentős, annak tudatában, hogy a játékos ennyi ideig nem tud teljes értékű munkát végezni.

\section{Súlyos sérülések (> 28 nap):}

Ezek a sérülések a legnehezebben meghatározhatóak, így ezeknek a kalkulálására konkrét példákat szeretnék kiemelni. A tanulmányban kimutatták, hogy a leggyakrabban előforduló sérülés a súlyosabbak közül a combhajlító, a belső oldalszalag és a közelítő izmok elváltozása. Az átlagos csapat (átlag alapján) 8 súlyos sérülést szenved el a szezonban a játékosállománya tekintetében, mely sérüléseknek az átlagos felépülési idejét 37 napban határozták meg. Amennyiben 300 napos szezonnal kalkulálunk, úgy ez a teljes szezon 12\%-át jelenti egy játékos számára. Ezekkel a számokkal a bérek tekintetében 3205458 Ft kiadásra számíthat a csapat egy sérült játékosnál, ami a statisztikákban kimutatott 8 esettel kalkulálva 25643664 Ft költséget jelent egy szezonban.

\begin{tabular}{|c|c|c|c|c|}
\hline $\begin{array}{c}\text { Sérülések } \\
\text { súlyossága: }\end{array}$ & Középérték & Bérköltség & $\begin{array}{c}\text { Produktivitási bónusz } \\
90 \text { perc esetén }\end{array}$ & $\begin{array}{c}\text { Elvesztett } \\
\text { produktivitás } \\
\text { aránya }\end{array}$ \\
\hline $1-3$ nap & 2 & $173268 \mathrm{Ft}$ & $360000 \mathrm{Ft}$ & 0,48 \\
\hline $4-7$ nap & 5,5 & $476487 \mathrm{Ft}$ & $360000 \mathrm{Ft}$ & 1,32 \\
\hline $8-28$ nap & 18 & $1559412 \mathrm{Ft}$ & $360000 \mathrm{Ft}$ & 4,33 \\
\hline $28+$ & 37 (átlag) & $3205458 \mathrm{Ft}$ & $360000 \mathrm{Ft}$ & 8,90 \\
\hline
\end{tabular}

2. táblázat: A sérülésekkel kapcsolatos költségek összevetése

Forrás: Saját szerkesztés Ekstrand (2009) és saját kutatás alapján

Amint a 2. táblázatból is láthatjuk, már az enyhébb sérülés is nagyobb veszteséget okoz a csapatnak, mint amit egy saját nevelésű fiatal 90 perces szerepeltetése eredményez. Ahogy a súlyosabb sérüléseket vizsgáljuk, tisztán látható, hogy ezek már önmagukban többszörös veszteséget jelentenek, mely egy olyan csapat esetében, aki nem tud megfelelő számú saját nevelésű játékost szerepeltetni akár több mérkőzés produktivitási bónuszát is felemészti. 


\section{Összegzés}

Amint láthattuk, a játékosok értékével párhuzamosan a számukra kifizetett bérek is növekedést mutatnak. Ezek a játékosok immár a modern futball legértékesebb és legnehezebben pótolható erőforrásává váltak, melyet hűen tükröz az átlagos napi bére egy Magyarországon igazolt játékosnak. Az elvárt teljesítmények növekedésével a sérülések száma is rohamosan gyarapodik. A korábbi kutatásokból kiderült, hogy milyen kategóriába lehet sorolni a sérüléseket súlyosságukat tekintve. Ha a bérköltség tekintetében vizsgáljuk meg, felfedezhető, hogy már a legrövidebb kihagyások is több százezer forintos „fölösleges” kiadást jelentenek a sportvállalkozások számára. Ha a súlyosabb sérüléseket is számításba vesszük, akkor már komoly, milliós nagyságrendü károk érik a csapatokat. Ennek tudatában kijelenthető, hogy a klubok prevenciós intézkedései ma már nem csak a játékosok egészségének megóvása, hanem a gazdasági eredményesség tekintetében is fontos szemponttá vált.

A publikáció elkészítését az EFOP-3.6.2-16-2017-00003 számú projekt támogatta. A projekt az Európai Unió támogatásával, az Európai Szociális Alap társfinanszírozásával valósult meg.

\section{Hivatkozott források}

[1.] Bácsné Bába É., Bács B. A., Bács Z. (2018): Hazai professzionális labdarúgó klubok iparági elemzése - A magyar labdarúgás Pénz Ligája 2014-2016. International Journal of Engineering and Management Sciences / Müszaki és Menedzsment Tudományi Közlemények Vol. 3 (2018) : No.5 pp. 284-296. Paper: DOI: 10.21791/IJEMS.2018.5.29, 13 p. (2018)

[2.] Bahr, R.- Mechelen, W. (2002): Prevention of sports injuries. M. Kjær, M. Krogsgaard, P. Magnusson, L. Engebretsen, H. Roos, T. Takala \& S. L.Y. Woo (eds) Textbook of Sports Medicine. Basic Science and Clinical Aspects of Sports Injury and Physical Activity. pp. 299-314. Blackwell Science, Oxford

[3.] Drawer S, - Fuller CW. (2002) Evaluating the level of injury in english professional football using a risk based assessment process. Br J Sports Med 36:446-51, DOI: 10.1136/bjsm.36.6.446

[4.] Ekstrand J.- Waldén M. (2009): Injury incidence and injury patterns in professional football: the UEFA injury study. Br J Sports Med. Dec; 19 (6):819-27, DOI: 10.1136/bjsm.2009.060582 
[5.] Fuller CW. et al. (2006): Consensus statement on injury definitions and data collection procedures in studies of football (soccer) injuries. Scand J Med Sci Sports. 16:83-92, DOI: 10.1136/bjsm.2005.025270

[6.] Liu W, et al (2014): Important issues concerning use of the term 'copers' in chronic ankle instability research. J Sports Med Volume 44, Issue 12, pp 1775-1776, DOI: 10.1007/s40279-014-0279-2

[7.] UEFA:(2018)https://www.uefa.com/MultimediaFiles/Download/ OfficialDocument/uefaorg/Finance/02/59/06/02/2590602_ DOWNLOAD.pdf letöltés dátuma: 2019. 03. 11.

\section{Szerzők:}

\section{Szalánczi Zoltán}

Sportközgazdász MSc

Debreceni Egyetem Gazdaságtudományi Kar

2. Évfolyam

szalanczi.zoltan@gmail.com 